\title{
Involvement of calcium in pain and antinociception
}

W.A. Prado

\author{
Correspondence \\ W.A. Prado \\ Departamento de Farmacologia \\ FMRP, USP \\ Av. Bandeirantes, 3900 \\ 14049-900 Ribeirão Preto, SP \\ Brasil \\ Fax + 55-16-633-2301 \\ E-mail: wadprado@fmrp.usp.br \\ Research supported by FAPESP \\ and CNPq. \\ Dr. Cesar Timo-laria has acted \\ as Editor for this manuscript.
}

Received December 5, 2000

Accepted February 6, 2001
Departamento de Farmacologia, Faculdade de Medicina de Ribeirão Preto, Universidade de São Paulo, Ribeirão Preto, SP, Brasil

\section{Abstract}

Calcium ions are widely recognized to play a fundamental role in the regulation of several biological processes. Transient changes in cytoplasmic calcium ion concentration represent a key step for neurotransmitter release and the modulation of cell membrane excitability. Evidence has accumulated for the involvement of calcium ions also in nociception and antinociception, including the analgesic effects produced by opioids. The combination of opioids with drugs able to interfere with calcium ion functions in neurons has been pointed out as a useful alternative for safer clinical pain management. Alternatively, drugs that reduce the flux of calcium ions into neurons have been indicated as analgesic alternatives to opioids. This article reviews the manners by which calcium ions penetrate cell membranes and the changes in these mechanisms caused by opioids and calcium antagonists regarding nociceptive and antinociceptive events.

\section{Introduction}

During the past few years evidence has accumulated about the property of opioid agonists to modify membrane excitability and intracellular signaling by direct or indirect modification of the transmembrane flux of calcium ions $\left(\mathrm{Ca}^{2+}\right)$. Among other alternatives presently under investigation, the combination of opioids with drugs able to interfere with $\mathrm{Ca}^{2+}$ function in neurons has been pointed out as a useful procedure to obtain safer clinical pain management. The author reviews here how $\mathrm{Ca}^{2+}$ enters cells and the changes in this process caused by opioids and $\mathrm{Ca}^{2+}$ antagonists regarding nociceptive and antinociceptive events.

\section{$\mathrm{Ca}^{2+}$ and $\mathrm{Ca}^{2+}$-channels}

Calcium is widely recognized to play a

\section{Key words}

- Antinociception

- Analgesia

- Calcium ions

- Calcium antagonists

- Opioids fundamental role in the regulation of several biological processes. A transient increase in cytoplasmic $\mathrm{Ca}^{2+}$ concentration represents a key step for neurotransmitter release and the modulation of cell membrane excitability, and depends on the passage of $\mathrm{Ca}^{2+}$ through membrane channels, transport by ion pumps, or release of $\mathrm{Ca}^{2+}$ from internal stores (for a review, see Ref. 1).

$\mathrm{Ca}^{2+}$ influx occurs via three main pathways (for a review, see Ref. 2): the voltageoperated calcium channels (VOCC), which are opened by membrane depolarization, the ligand-gated nonspecific calcium channels, and the receptor-activated calcium channels (RACC). Two main types of RACC have been described: the store-operated, or capacitative, calcium channels and the intracellular messenger-activated nonselective channels. The VOCC give rapid but brief $\mathrm{Ca}^{2+}$ pulses, whereas RACC produce rapid 
but sustained elevation in intracellular $\mathrm{Ca}^{2+}$. Also, the mobilization of $\mathrm{Ca}^{2+}$ from internal stores, a mechanism known as $\mathrm{Ca}^{2+}$-induced $\mathrm{Ca}^{2+}$ release, may amplify the $\mathrm{Ca}^{2+}$ signal initiated by the opening of VOCC.

The calcium channels consist of heterooligomeric complexes containing at least $\beta$ and $\alpha_{2} \delta$ subunits functionally stabilized by a central $\alpha_{1}$ subunit, which forms the ion pore. Molecular cloning has identified nine calcium channel $\alpha_{1}$ subunit genes $\left(\alpha_{1 \mathrm{~A}}\right.$ to $\alpha_{1 \mathrm{E}}$, $\left.\alpha_{1 S}\right)$, four $\beta$ subunit genes $\left(\beta_{1}-\beta_{4}\right)$, and a single gene encoding an $\alpha_{2} \delta$ subunit. The central $\alpha_{1}$ subunit carries the channel's $\mathrm{Ca}^{2+}$ selectivity filter, controls its voltage-dependent opening and closing via its voltage sensors, and also determines its distinct pharmacological properties. The VOCC were classified into low-threshold (or T-type) and high-threshold activated channels. At least four types of high-threshold activated channels have been defined: the L-, N-, P/Q-, and R-types. The localization, possible functions, and sensitivity of VOCC to drugs are summarized in Table 1. More recent studies have provided evidence for the involvement of a membrane-delimited $\mathrm{G}$ protein $\left(\mathrm{G}_{\beta \gamma}\right.$ subunit)- dependent pathway in the modulation of $\mathrm{N}$ type and $\mathrm{P} / \mathrm{Q}$-type channels.

The cations $\mathrm{Ce}^{3+}, \mathrm{La}^{3+}, \mathrm{Nd}^{3+}, \mathrm{Cd}^{2+}, \mathrm{Co}^{2+}$, $\mathrm{Ni}^{2+}, \mathrm{Mg}^{2+}$ and $\mathrm{Mn}^{2+}$ block the $\mathrm{Ca}^{2+}$-channel pore in a nonselective manner and prevent $\mathrm{Ca}^{2+}$ from entering the cells (see Ref. 2). More selective agents include antagonists of L-type VOCC, which are classified as dihydropyridines, benzothiazepines, phenylalkylamines and diphenylalkylamines; antagonists of N-type VOCC, such as $\omega$-conotoxin GVIA $(\omega$-CgTX), obtained from the marine snail Conus geographus and its synthetic equivalents, and antagonists of P-type VOCC, represented by the funnel web spider toxin, $\omega$ agatoxin GIVA ( $\omega$-AgaTX). Aminoglycoside antibiotics (such as streptomycin, kanamycin, neomycin, gentamicin, and amikacin) have been described as N-type (for a review, see Ref. 3) and P/Q-type (4) antagonists.

\section{$\mathrm{Ca}^{2+}-$ channels and nociception}

The L-, N- and P/Q-type $\mathrm{Ca}^{2+}$-channels were demonstrated in the dorsal horn of the spinal cord (for a review, see Ref. 5). The Ltype $\mathrm{Ca}^{2+}$-channels were found in proximal

\begin{tabular}{|c|c|c|c|c|}
\hline Type & $\alpha_{1}$ Subunit & Location & $\begin{array}{l}\text { Activation } \\
\text { threshold }\end{array}$ & Antagonist \\
\hline \multirow{3}{*}{ L } & $\mathrm{C}$ & $\begin{array}{l}\text { Cardiac/smooth } \\
\text { muscles }\end{array}$ & \multirow{3}{*}{$>-30 \mathrm{mV}$} & $\begin{array}{l}\text { Dihydropyridines: nifedipine, nimodipine, } \\
\text { felodipine, nitrendipine, nisoldipine, nicardipine }\end{array}$ \\
\hline & $\mathrm{D}$ & Neuroendocrine & & Benzothiazepines: diltiazem \\
\hline & $\mathrm{S}$ & Skeletal muscle & & $\begin{array}{l}\text { Phenylalkylamine: verapamil } \\
\text { Diphenylalkylamines: flunarizine, cinnarizine }\end{array}$ \\
\hline $\mathrm{P} / \mathrm{Q}$ & A & Neuron & $>-30 \mathrm{mV}$ & $\omega$-agatoxin GIVA \\
\hline $\mathrm{N}$ & B & Neuron & $>-30 \mathrm{mV}$ & $\omega$-conotoxin GVIA, SNX-111, SNX-159, SNX-239 \\
\hline $\mathrm{R}$ & $\mathrm{E}$ & Neuron & $>-30 \mathrm{mV}$ & Not available \\
\hline $\mathrm{T}$ & $\begin{array}{l}\mathrm{G} \\
\mathrm{H}\end{array}$ & Widespread & $>-70 \mathrm{mV}$ & Amiloride, octanol, nonanol, decanol \\
\hline
\end{tabular}


dendrites and cellular bodies of neurons in the CNS, and in the subsynaptic membrane of some glutamatergic synapses. The N-type $\mathrm{Ca}^{2+}$-channels are concentrated in presynaptic nerve terminals at the level of the more superficial laminae I and II of the dorsal horn of the spinal cord, a strategic location for a key role of these channels in neurotransmitter release from primary afferents. The Ltype $\mathrm{Ca}^{2+}$-channels seem to be more important for the regulation of cellular calciumdependent events than for the neurotransmitter itself. They participate in the excitation-transcription coupling but are not necessary for fast synaptic transmission. Antagonists of the $\mathrm{N}$-type $\mathrm{Ca}^{2+}$-channels block the release of sensory neuropeptides from primary sensory neurons in culture. Also, N- and P/Q-type channels mediate fast synaptic transmission at virtually all chemical synapses. Thus, N-type channels and probably P-type channels can play a fundamental role in the modulation of nociceptive information, whereas the involvement of L-type channels in the process seems to be very restricted.

\section{Nociception and $\mathrm{Ca}^{2+}$ availability}

There are several lines of evidence for the involvement of $\mathrm{Ca}^{2+}$ in nociception (for references, see Table 2). The intracerebroventricular (icv) administration of calcium chloride produces hyperalgesia or has no effect in mouse models of pain. In contrast, intrathecal (it) calcium chloride produced

Table 2 - Effects of $\mathrm{Ca}^{2+}$, a Ca${ }^{2+}$ agonist, $\mathrm{Ca}^{2+}$ ionophores or $\mathrm{Ca}^{2+}$ chelators on nociception and opioid-induced antinociception.

\begin{tabular}{|c|c|c|c|c|c|c|}
\hline Drug & Animal & Route & Dose & Test & Effect & Reference \\
\hline \multirow{5}{*}{$\mathrm{CaCl}_{2}$} & \multirow{5}{*}{ Mouse } & icv & $0.1-0.5 \mu \mathrm{mol}$ & TIT & Hyperalgesia & 9 \\
\hline & & icv & $50-200 \mathrm{nmol}$ & TFT & No effect (alone); $\downarrow$ MPA & 10 \\
\hline & & icv & $15 \mu \mathrm{mol} / \mathrm{kg}$ & TFT & No effect (alone); $\downarrow$ MPA & 11 \\
\hline & & it & $600 \mathrm{nmol}$ & TFT & Antinociception $\downarrow$ by naloxone or naltrindole & 6 \\
\hline & & it & $0.02-1 \mu \mathrm{mol}$ & WT & Antinociception & 12 \\
\hline \multirow{6}{*}{ BAY K 8644} & \multirow{3}{*}{ Mouse } & sc & $0.05-5 \mathrm{mg} / \mathrm{kg}$ & WT & Antinociception & 13 \\
\hline & & sc & $0.2 \mathrm{mg} / \mathrm{kg}$ & WT/HPT/TCT & $\uparrow M P A$ & 14 \\
\hline & & vo & $0.5-2.0 \mathrm{mg} / \mathrm{kg}$ & HPT & Antinociception & 15 \\
\hline & \multirow[t]{3}{*}{ Rat } & ip & $20-200 \mu \mathrm{g} / \mathrm{kg}$ & TFT & $\begin{array}{l}\text { No effect (alone); low dose } \downarrow \text { and } \\
\text { high dose } \uparrow \text { analgesia by sufentanil }\end{array}$ & 16 \\
\hline & & ip & $100 \mu \mathrm{g} / \mathrm{kg}$ & VT & No effect (alone) & 17 \\
\hline & & it & $1 \mu \mathrm{g}$ & FT & $\uparrow 1$ st and 2 nd phases & 7 \\
\hline A23187 & Rat & it & $1 \mu g$ & FT & $\uparrow$ 1st and 2nd phases & 7 \\
\hline X537A & Mouse & icv & $1 \mu \mathrm{mol} / \mathrm{kg}$ & TFT & No effect alone ( $\uparrow \mathrm{Ca}^{2+}$-induced $\left.\downarrow \mathrm{MPA}\right)$ & 11 \\
\hline \multirow[t]{2}{*}{ EDTA } & Mouse & icv & $4 \mu \mathrm{mol} / \mathrm{kg}$ & TFT & No effect on MPA & 11 \\
\hline & & icv & $0.5-1 \mu \mathrm{mol} / \mathrm{kg}$ & TIT & No effect (alone); $\uparrow$ analgesia by $\kappa$-agonists & 9 \\
\hline \multirow[t]{2}{*}{ EGTA } & Mouse & icv & $0.025-0.1 \mu \mathrm{mol}$ & TFT & Antinociception & 17 \\
\hline & & icv & $2 \mu \mathrm{mol} / \mathrm{kg}$ & TFT & $\uparrow \mathrm{MPA}$ & 11 \\
\hline Quin-2 & Rat & it & $1 \mu \mathrm{g}$ & $\mathrm{FT}$ & $\downarrow$ 2nd phase & 7 \\
\hline
\end{tabular}


naloxone- or naltrindole-sensitive antinociception in the mouse tail-flick or writhing test, an effect imputed to a $\mathrm{Ca}^{2+}$-induced spinal release of met-enkephalin (for a review, see Ref. 6).

Some experiments were conducted using drugs that increase the level of intracellular $\mathrm{Ca}^{2+}$, such as $\mathrm{Ca}^{2+}$ ionophores (X537A and A23187) or $\mathrm{Ca}^{2+}$ agonists (BAY K 8644), yielding conflicting results. The icv administration of X537A did not change the nociceptive response of mice to thermal noxious stimuli, whereas the it administration of A23187 significantly elevated both phases of the response to formalin in rats. BAY K 8644 was ineffective in the rat tail-flick test following intraperitoneal (ip) administration, but produced antinociception in the mouse hot-plate or writhing test following subcutaneous ( $s c$ ) or intravenous (iv) administration, respectively. In contrast, it BAY $\mathrm{K}$ 8644 increased the response of rats to formalin, thus indicating a critical role of intracellular $\mathrm{Ca}^{2+}$ level for the development of persistent pain in response to formalin (7). The dose of BAY K 8644 used in each case accounts for the differences (see ahead).

Other studies were conducted using $\mathrm{Ca}^{2+}$ chelators such as EDTA, EGTA or Quin-2. EGTA alone administered icv had no effect or produced dose-dependent antinociception in mice. EDTA alone had a weak or no antinociceptive effect in mice. Quin-2 administered it reduced the second, but not the first phase of the formalin test in rodents, thus indicating a critical involvement of $\mathrm{Ca}^{2+}$ influx in mediating central sensitization following tissue injury, but not in the transmission of inputs in response to brief noxious stimuli (7).

Evidence also exists for the involvement of $\mathrm{Ca}^{2+}$ in peripheral mechanisms mediated at the nociceptor level. The intraplantar administration of A23187 evokes hyperalgesia in rats that is potentiated by methylxanthines and antagonized by verapamil, $\mathrm{La}^{3+}$ or morphine, thus indicating that the hyperalgesic effect of the $\mathrm{Ca}^{2+}$ ionophore depends on the activity of adenylate cyclase on peripheral nociceptors (8).

\section{$\mathrm{Ca}^{2+}$-channel antagonists and antinociception}

Several $\mathrm{Ca}^{2+}$-channel antagonists have been used for the study of the effects of $\mathrm{Ca}^{2+}$ on nociception. Trivalent cations such as $\mathrm{La}^{3+}$ and $\mathrm{Ce}^{3+}$ produce antinociception in both the tail-flick and hot-plate tests following $i c v$ administration to mice $(11,17)$. Intrathecal $\mathrm{La}^{3+}$ or $\mathrm{Nd}^{3+}$ also produces antinociception in the rat tail-flick and hot-plate tests and blocks both phases of the response to formalin in rats (18). Since the development of the 2nd phase (persistent pain) of the response to formalin depends on the occurrence of the 1st phase (phasic pain), the effects of the inorganic cations against both phases of the response indicate that VOCC are involved in both the induction and maintenance of the response to formalin (18). Intrathecal $\mathrm{Ni}^{2+}$, which preferentially blocks T-type VOCC, was ineffective in the mouse writhing test, thus indicating that T-type channels are not implicated in the spinal processing of nociceptive information (12).

The effects of L-type $\mathrm{Ca}^{2+}$-channel antagonists on nociception differ depending on the drug, dosage, and route of administration and algesimetric test used (for references, see Table 3). In general, the antinociception induced by the L-type $\mathrm{Ca}^{2+}$-channel antagonists was demonstrated in rodents mainly when models of persistent pain, such as the writhing and formalin tests, were used. However, it diltiazem or verapamil has failed to reduce the persistent hyperalgesia induced by chronic sciatic ligature in rats, also a model of persistent pain. The remaining data on the effects of L-type $\mathrm{Ca}^{2+}$-channel antagonists indicate that the drugs, whatever the route of administration, had little or no effect in models of phasic pain. More recently, Weissman and colleagues (19) have 
Table 3 - Effects of L-type $\mathrm{Ca}^{2+}$-channel antagonists on nociception and opioid-induced antinociception.

$\mathrm{CSL}=$ Chronic sciatic ligature; DHC = dorsal horn cell electrical activity. For other abbreviations see legend to Table 2.

\begin{tabular}{|c|c|c|c|c|c|c|}
\hline Drug & Animal & Route & Dose & Test & Effect & Reference \\
\hline \multirow{13}{*}{ Diltiazem } & \multirow{8}{*}{ Mouse } & icv & $0.5-400 \mu \mathrm{g} / \mathrm{kg}$ & WT & Antinociception (alone) & 20 \\
\hline & & icv & $60-120 \mu \mathrm{g}$ & HPT & Antinociception (alone); $\uparrow$ MPA & 21 \\
\hline & & sc & $60-120 \mu g$ & HPT & No effect (alone); $\uparrow$ MPA & 21 \\
\hline & & sc & $15 \mathrm{mg} / \mathrm{kg}$ & HPT & No effect (alone); $\uparrow$ MPA & 22 \\
\hline & & sc & $10-40 \mathrm{mg} / \mathrm{kg}$ & WT & Antinociception (alone) & 13 \\
\hline & & sc & $10-30 \mathrm{mg} / \mathrm{kg}$ & WT & Antinociception (alone) & 23 \\
\hline & & ip & $1-30 \mathrm{mg} / \mathrm{kg}$ & WT/HPT & No effect (alone) & 24 \\
\hline & & it & $0.5-80 \mu \mathrm{g}$ & WT & Antinociception (alone) & 12 \\
\hline & \multirow{5}{*}{ Rat } & sc & $20 \mathrm{mg} / \mathrm{kg}$ & HPT & No effect (alone); $\uparrow$ MPA & 25 \\
\hline & & ip & $1-30 \mathrm{mg} / \mathrm{kg}$ & FT & Antinociception (alone) & 24 \\
\hline & & it & $3 \mu \mathrm{g}$ & CSL & No effect (alone) & 26 \\
\hline & & it & $100 \mu \mathrm{g}$ & TFT & No effect (alone); $\uparrow$ MPA & 27 \\
\hline & & it & $100 \mu \mathrm{g}$ & FT & Minimal antinociception (alone) & 18 \\
\hline \multirow{18}{*}{ Verapamil } & \multirow{10}{*}{ Mouse } & icv & $0.5-400 \mu \mathrm{g} / \mathrm{kg}$ & WT & Antinociception (alone) & 20 \\
\hline & & icv & $15-120 \mu \mathrm{g}$ & HPT & Antinociception (alone); $\uparrow$ MPA & 21 \\
\hline & & icv & $25-200 \mu g$ & HPT & Antinociception (alone) & 19 \\
\hline & & SC & $20 \mu g$ & HPT & No effect (alone); $\uparrow$ MPA & 12 \\
\hline & & sc & $10-80 \mathrm{mg} / \mathrm{kg}$ & HPT & Weak antinociception & 19 \\
\hline & & sc & $5-20 \mathrm{mg} / \mathrm{kg}$ & WT & Antinociception (alone) & 22 \\
\hline & & sc & $2-30 \mathrm{mg} / \mathrm{kg}$ & WT & Antinociception (alone) & 24 \\
\hline & & ip & $1-30 \mathrm{mg} / \mathrm{kg}$ & WT/HPT & No effect (alone) & 13 \\
\hline & & it & $0.5-80 \mu \mathrm{g}$ & WT & Antinociception (alone) & 23 \\
\hline & & it & $25-200 \mu \mathrm{g}$ & HPT & Antinociception (alone) & 19 \\
\hline & \multirow{8}{*}{ Rat } & icv & $20 \mathrm{nmol}$ & TFT/HPT & $\uparrow$ analgesia of DAMGO; $\downarrow$ analgesia of DPDPE & 28 \\
\hline & & SC & $10 \mathrm{mg} / \mathrm{kg}$ & HPT & No effect (alone); $\uparrow$ MPA & 25 \\
\hline & & ip & $1-30 \mathrm{mg} / \mathrm{kg}$ & FT & Antinociception (alone) & 24 \\
\hline & & it & 5 and $50 \mu \mathrm{g}$ & $\mathrm{FT} / \mathrm{DHC}$ & No effect (alone) & 29 \\
\hline & & it & $100 \mu \mathrm{g}$ & FT & Minimal antinociception (alone) & 18 \\
\hline & & it & $10 \mu \mathrm{g}$ & $\mathrm{FT}$ & $\downarrow$ 2nd phase (alone) & 7 \\
\hline & & it & $250 \mu \mathrm{g}$ & CSL & No effect (alone) & 26 \\
\hline & & it & $50 \mu \mathrm{g}$ & TFT & No effect (alone); $\uparrow$ MPA & 27 \\
\hline \multirow{11}{*}{ Nifedipine } & \multirow{5}{*}{ Mouse } & icv & $0.5-400 \mu \mathrm{g} / \mathrm{kg}$ & WT & Antinociception (alone) & 20 \\
\hline & & sc & $15 \mathrm{mg} / \mathrm{kg}$ & HPT & No effect (alone); no change in MPA & 22 \\
\hline & & sc & $5-20 \mathrm{mg} / \mathrm{kg}$ & WT & Antinociception (alone) & 13 \\
\hline & & sc & $2-20 \mathrm{mg} / \mathrm{kg}$ & WT & Antinociception (alone) & 23 \\
\hline & & ip & $1-30 \mathrm{mg} / \mathrm{kg}$ & WT/HPT & No effect (alone) & 24 \\
\hline & \multirow{6}{*}{ Rat } & ip & $1-30 \mathrm{mg} / \mathrm{kg}$ & FT & Antinociception (alone) & 24 \\
\hline & & ip & $2 \mathrm{mg} / \mathrm{kg}$ & TFT & $\uparrow \mathrm{MPA}$ & 30 \\
\hline & & it & $24 \mathrm{nmol}$ & $\mathrm{FT}$ & Minimal antinociception (alone) & 18 \\
\hline & & it & $10 \mu \mathrm{g}$ & $\mathrm{FT}$ & $\downarrow$ 2nd phase (alone) & 7 \\
\hline & & it & $0.8-7.0 \mu \mathrm{g}$ & TFT/HPT & Antinociception (alone) & 31 \\
\hline & & it & 50 and $100 \mu \mathrm{g}$ & TFT & No effect (alone) & 32 \\
\hline
\end{tabular}


Table 3 - Continued.

\begin{tabular}{|c|c|c|c|c|c|c|}
\hline Drug & Animal & Route & Dose & Test & Effect & Reference \\
\hline \multirow{11}{*}{ Nimodipine } & \multirow{5}{*}{ Mouse } & icv & $0.5-400 \mu \mathrm{g} / \mathrm{kg}$ & WT & Antinociception (alone) & 20 \\
\hline & & icv & $5 \mu \mathrm{g}$ & TFT & No effect (alone); $\downarrow$ MPA & 10 \\
\hline & & vo & $<100 \mathrm{mg} / \mathrm{kg}$ & HPT & No effect (alone); $\uparrow$ fentanyl-induced analgesia & 15 \\
\hline & & sc & $20 \mathrm{mg} / \mathrm{kg}$ & WT/HPT & $\uparrow \mathrm{MPA}$ & 14 \\
\hline & & ip & $1-30 \mathrm{mg} / \mathrm{kg}$ & WT/HPT & Antinociception (alone) & 24 \\
\hline & \multirow{6}{*}{ Rat } & iv & $<100 \mathrm{mg} / \mathrm{kg}$ & VT & No effect (alone) & 15 \\
\hline & & ip & $200 \mu \mathrm{g} / \mathrm{kg}$ & TFT & No effect (alone); $\uparrow$ sufentanil-induced analgesia & 16 \\
\hline & & ip & $200 \mu \mathrm{g} / \mathrm{kg}$ & TFT & No effect (alone); $\downarrow$ U69593-induced analgesia & 33 \\
\hline & & ip & $1-30 \mathrm{mg} / \mathrm{kg}$ & FT & Antinociception (alone) & 24 \\
\hline & & it & $50-100 \mu \mathrm{g} / \mathrm{kg}$ & TFT & No effect (alone) & 32 \\
\hline & & it & $60-240 \mathrm{pmol}$ & TFT & No effect (alone); $\downarrow$ antinociception by DAMGO & 34 \\
\hline \multirow{3}{*}{ Nicardipine } & \multirow[t]{2}{*}{ Mouse } & sc & $15-20 \mathrm{mg} / \mathrm{kg}$ & HPT & No effect (alone); $\uparrow$ MPA & 22 \\
\hline & & it & $0.5-80 \mu \mathrm{g}$ & WT & Antinociception (alone) & 12 \\
\hline & Rat & it & $20 \mu \mathrm{g}$ & TFT & No effect (alone); $\uparrow$ MPA & 27 \\
\hline \multirow{5}{*}{ Flunarizine } & \multirow{5}{*}{ Mouse } & icv & $0.5-400 \mu \mathrm{g} / \mathrm{kg}$ & WT & Antinociception (alone) & 20 \\
\hline & & icv & $1-200 \mu \mathrm{g}$ & HPT & Antinociception (alone) & 19 \\
\hline & & sc & $20 \mathrm{mg} / \mathrm{kg}$ & HPT & No effect (alone); $\uparrow$ MPA & 22 \\
\hline & & sc & $5-80 \mathrm{mg} / \mathrm{kg}$ & HPT & Antinociception (alone) & 19 \\
\hline & & it & $1-200 \mu \mathrm{g}$ & HPT & Antinociception (alone) & 19 \\
\hline \multirow[t]{2}{*}{ Cinnarizine } & \multirow[t]{2}{*}{ Rat } & ip & $6-480 \mu \mathrm{g} / \mathrm{kg}$ & TFT & Antinociception (alone) & 32 \\
\hline & & it & $3-9 \mu \mathrm{g}$ & TFT & Antinociception (alone) & 32 \\
\hline
\end{tabular}

demonstrated that verapamil and flunarizine evoke antinociception in the mouse hot-plate test. Using specific opioid antagonists, they showed that these effects might be due to the agonistic activity of verapamil at $\mu-, \delta$ - and $\kappa_{3}$-receptor subtypes. Flunarizine had a mixed opioid activity, acting as an agonist on $\mu$ receptors and as an antagonist on $\delta$ - and $\kappa$ receptor subtypes. In a comparative study, it verapamil or nifedipine was less effective than it Quin-2 in reducing the 2nd phase of the rat response to formalin, results that were interpreted as evidence that $\mathrm{Ca}^{2+}$ influx through channels other than phenylalkylamine- and dihydropyridine-sensitive VOCC may be involved in the process (7).

The effects of N-type $\mathrm{Ca}^{2+}$-channel antagonists on nociception may also differ depending on the route of administration and pain model used (for references, see Table 4). In general, the conopeptides $\omega$-CgTX and SNX-111 produce weak antinociception in rodent models of phasic pain, but are usually very effective in models of persistent pain. Other conopeptides, SNX-239 and SNX-159, were very effective following it administration in the rat hot-plate or formalin tests and significantly reduced the allodynia evoked by chronic sciatic ligature. Differently from opiates, the continuous infusion of SNX-111 or SNX-239 reduces both phases of the formalin test in rats accompanied by no signs of tolerance (35). The site of the antinociceptive effect of N-type antagonists seems to be within the CNS since they were effective following $i t$, but not systemic or topical application (26).

Aminoglycoside antibiotics have been demonstrated to interact competitively with $\mathrm{Ca}^{2+}$ in several processes including neurotransmitter release in peripheral synapses (for a review, see Ref. 36). We have exam- 


\begin{tabular}{|c|c|c|c|c|c|c|}
\hline Drug & Animal & Route & Dose & Test & Effect & Reference \\
\hline \multirow{6}{*}{$\omega$-Conotoxin } & Mouse & icv & $10-100 \mathrm{ng}$ & TFT & No effect (alone); $\uparrow$ MPA & 10 \\
\hline & \multirow{5}{*}{ Rat } & icv & $24 \mathrm{ng}$ & TFT & $\uparrow$ Analgesia by DAMGO; $\downarrow$ analgesia by DPDPE & 28 \\
\hline & & icv & $20 \mathrm{ng}$ & TFT & Weak antinociception; $\uparrow$ MPA & 38 \\
\hline & & ip & $5-10 \mu \mathrm{g} / \mathrm{kg}$ & TFT & Weak antinociception; $\uparrow$ MPA & 38 \\
\hline & & it & $0.1-0.4 \mu \mathrm{g}$ & $\mathrm{FT} / \mathrm{DHC}$ & $\downarrow 1$ st and 2nd phases & 29 \\
\hline & & it & $16-64 \mathrm{pmol}$ & TFT & Antinociception; $\uparrow$ DADLE-induced antinociception & 34 \\
\hline \multirow{8}{*}{ SNX-111 } & \multirow{8}{*}{ Rat } & iv & $3 \mathrm{mg} / \mathrm{kg}$ & PIP & No effect & 39 \\
\hline & & it & $0.82-14 \mathrm{ng} / \mathrm{h}$ & FT & Low dose $\downarrow$ 2nd phase; high dose $\downarrow$ both phases & 40 \\
\hline & & it & $100 \mathrm{ng}$ & $\mathrm{FT}$ & $\downarrow$ 2nd phase & 40 \\
\hline & & it & $30-300 \mathrm{ng}$ & CSL & Antinociception; dose-dependent & 40 \\
\hline & & it & $30-300 \mathrm{ng}$ & PIP & Antinociception & 39 \\
\hline & & it & $3-300 \mu \mathrm{mol} / \mathrm{h}$ & FT/HPT & Antinociception & 35 \\
\hline & & it & $0.1-1.0 \mu \mathrm{g}$ & FT/HPT & $\downarrow$ 2nd phase; no effect in the HPT & 41 \\
\hline & & it & $3.0 \mu \mathrm{g}$ & CSL & $\downarrow$ Allodynia & 26 \\
\hline \multirow[t]{2}{*}{ SNX-239 } & \multirow[t]{2}{*}{ Rat } & it & $0.29 \mathrm{nmol} / \mathrm{h}$ & FT/HPT & Antinociception & 35 \\
\hline & & it & $3.3 \mu \mathrm{g}$ & CSL & $\downarrow$ Allodynia & 26 \\
\hline SNX-159 & Rat & it & $4.0 \mu \mathrm{g}$ & CSL & $\downarrow$ Allodynia & 26 \\
\hline \multirow{7}{*}{ Gentamicin } & \multirow{3}{*}{ Mouse } & icv & $40-60 \mu \mathrm{g}$ & $\mathrm{HPT} / \mathrm{TFT}$ & Antinociception & 42 \\
\hline & & ip & $40-640 \mu \mathrm{g}$ & HPT & Antinociception (bell-shaped dose-response curve) & 37 \\
\hline & & ip & $0.5-4.0 \mu \mathrm{g}$ & WT & Antinociception & 12 \\
\hline & \multirow{4}{*}{ Rat } & icv & $20-80 \mu \mathrm{g}$ & TFT & Antinociception & 3 \\
\hline & & ip & $200-800 \mu g$ & IT & Antinociception & 37 \\
\hline & & ip & $10-320 \mu \mathrm{g}$ & TFT & Antinociception (bell-shaped dose-response curve) & 37 \\
\hline & & it & $1.25-25 \mu \mathrm{g}$ & TFT & Antinociception; $\uparrow$ MPA & 3 \\
\hline Neomycin & Mouse & it & $0.5-4.0 \mu \mathrm{g}$ & WT & Antinociception & 12 \\
\hline \multirow[t]{3}{*}{ Amikacin } & Mouse & sc/ip & $30 \mathrm{mg} / \mathrm{kg}$ & WT & Antinociception & 43 \\
\hline & & iv & $30 \mu \mathrm{g} / \mathrm{kg}$ & CSL & No effect & 26 \\
\hline & & it & $0.1 \mu \mathrm{g}$ & CSL & No effect & 26 \\
\hline \multirow[t]{3}{*}{$\omega$-Agatoxin } & Rat & it & $0.125-0.5 \mu \mathrm{g}$ & FT/DHC & $\downarrow$ 2nd phase & 29 \\
\hline & & it & $0.2-6 \mathrm{pmol}$ & FT & $\downarrow$ 1st phase; block 2nd phase & 18 \\
\hline & & it & $0.2-6 \mathrm{pmol}$ & HPT & No effect & 18 \\
\hline
\end{tabular}

ined the effects of gentamicin on the response of rodents to thermal noxious stimuli (tail-flick and hot-plate tests) and to a hyperalgesic stimulus (carrageenan-induced knee incapacitation) $(3,37)$. Gentamicin was antinociceptive in all tests when injected by the $i c v$, ip or it route. Marked and dose-dependent antinociception was obtained after it administration, whereas weaker effects and bell- shaped dose-response curves were obtained following ip or icv administration. The effect of $i$ gentamicin was transitory and dosedependently reversed by it calcium chloride. Gentamicin, neomycin and kanamycin were also effective in the mouse writhing, hotplate and tail-flick tests following $i c v$ or it administration, and $s c$ kanamycin and amikacin were effective in the rat hot-plate test. 
More recently, sc or ip amikacin was found to be antinociceptive also in the mouse writhing test. The effects of gentamicin and neomycin were not changed by naloxone, thus indicating that an opioid mechanism is unlikely to be involved in the effects of the antibiotics (12).

The P-type $\mathrm{Ca}^{2+}$-channel antagonist $\omega$ AgaTX was ineffective in the hot-plate test or against the hyperalgesia evoked by chronic sciatic ligature following $i v$ or it administration to rats. However, the it toxin was highly effective in suppressing the 2 nd phase of the rat response to formalin, but had no effect or a very modest suppressive effect against the 1st phase of the response to the same test. These results led to the notion that N-type, and possibly P-type, but not L-type VOCC antagonists exert a selective inhibitory effect on nociceptive transmission at the spinal cord level (18). In addition, N-type antagonists, but not $\omega$-AgaTX, were still effective against the 2nd phase of the response to formalin when injected after the 1st phase, thus indicating that $\mathrm{N}$ - and P-type VOCC play different roles in nociception (18).

\section{0 pioid agonists and $\mathrm{Ca}^{2+}$}

Opioid agonists reduce the intracellular $\mathrm{Ca}^{2+}$ concentration either indirectly, through a $\mu$ - or $\delta$-receptor-mediated increase in $\mathrm{Ca}^{2+}$ dependent $\mathrm{K}^{+}$conductance that leads to nerve cell hyperpolarization and shortening of the action potential duration, or directly through a $\kappa$-receptor-mediated shortening of $\mathrm{Ca}^{2+}$ action potentials without any change in the resting membrane potential (for a review, see Ref. 19). All the opioid receptors seem to share common mechanisms involving activation of $G$ protein $\beta \gamma$ or $\alpha$ subunit-mediated effects (for a review, see Ref. 44). Activation of cloned $\mu$-, $\delta$-, and $\kappa$-opioid receptors inhibits adenylyl cyclase activity via activation of inhibitory $\mathrm{G}$ proteins, thus reducing the $\mathrm{Ca}^{2+}$ influx, inhibits N-type and L-type VOCC via $\mathrm{G}_{\mathrm{o}}$ protein, and stimulates phos- phatidylinositol turnover, thus causing a transient increase in intracellular $\mathrm{Ca}^{2+}$ level. The $\mu$ - and $\delta$-receptor inhibition of adenylyl cyclase is mediated by $\mathrm{G}_{\mathrm{o}}$ and $\mathrm{G}_{\mathrm{i} 2}$ proteins, respectively, while the same effect via $\kappa$ receptor activation occurs without selectivity toward $\mathrm{G}_{\mathrm{i}} / \mathrm{G}_{\mathrm{o}}$ proteins. The activation of $\mathrm{G}$ proteins selectively modulates $\alpha_{1 \mathrm{~A}}$ and $\alpha_{1 \mathrm{~B}}$ subunits in a manner identical to that for native P/Q- and N-type currents, respectively, whereas $\alpha_{1 C}$ L-type currents do not exhibit G-protein sensitivity (for a review, see Ref. $1)$. Thus, reduction of the intracellular free $\mathrm{Ca}^{2+}$ concentration is the final result of stimulating different opioid receptors, but the interaction of $\mathrm{Ca}^{2+}$ antagonists with $\mu$ - or $\delta$ agonists may be expected to differ from the interaction with $\kappa$-agonists (27).

The electrical stimulation of certain supraspinal regions produces antinociception in a variety of laboratory animals and reduces chronic pain in human patients (for a review, see Ref. 45). The regions most extensively studied include the mesencephalic periaqueductal gray matter, locus coeruleus, parabrachial area, and the ventromedullar raphe magnus and reticularis gigantocellularis nuclei. The electrical stimulation of, or microinjection of morphine into these regions produces antinociception by activating centrifugal pathways that descend through the dorsolateral funiculus to inhibit the responses of dorsal horn neurons to peripheral noxious stimuli. In order to exert an inhibitory influence on spinal neurons, the descending pathways utilize at least serotonin and noradrenaline as neurotransmitters. The serotonergic mediation seems to depend on a further activation of spinal intrinsic enkephalin- or dynorphin-containing neurons. In contrast, noradrenergic mediation can inhibit spinal neurons either directly or indirectly via cholinergic intrinsic spinal neurons. We may therefore suspect that opioid agonists can interfere with nociceptive processing acting either supraspinally to activate descending pain-inhibitoring pathways, or spi- 
nally, to inhibit noxious inputs to dorsal horn neurons. On the other hand, pharmacological manipulations that interfere with $\mathrm{Ca}^{2+}$ availability can change nociceptive processing either supraspinally or spinally. Most of the studies reviewed here emphasize the spinal effects of calcium antagonists. To our knowledge, there is only one report showing that administration of $\mathrm{Ca}^{2+}$ into the periaqueductal gray produces a nonsignificant hyperalgesia in the rat tail-flick test but antagonizes the antinociceptive effect induced by iv morphine. The same study also demonstrates that administration of EGTA into the same region produces a dose-dependent antinociception in the same test (46).

\section{0 pioid-induced antinociception and $\mathrm{Ca}^{2+}$ availability}

Acute administration of opioid agonists to rodents reduces the $\mathrm{Ca}^{2+}$ content in synaptic vesicles, synaptosomes and several rat brain areas. In contrast, the vesicular content of $\mathrm{Ca}^{2+}$ in synaptosomes, the $\mathrm{Ca}^{2+}$ uptake, and mainly the $\mathrm{K}^{+}$-stimulated $\mathrm{Ca}^{2+}$ uptake by synaptosomes are increased during the development of opiate tolerance in rats. Parallel to these findings, opiate tolerance was correlated with an increase in the density of dihydropyridine-binding sites and higher basal free intracellular $\mathrm{Ca}^{2+}$ levels in the rat brain (for a review, see Ref. 47). Nimodipine, nifedipine and verapamil prevented the development of naloxone-precipitated withdrawal syndrome in rats (48). Previous, but not concurrent administration of nimodipine, prevented the development of tolerance to sufentanil in rats (16).

The literature has also provided several reports of changes produced by substances that interfere with $\mathrm{Ca}^{2+}$ influx or availability in opioid-induced antinociception (for references, see Tables 2 to 4). Intracerebroventricular calcium chloride reduced opioidinduced antinociception in mice. Subcutaneous BAY K 8644 increased morphine- induced antinociception in the mouse writhing, hot-plate and tail-clip tests. Low doses of BAY K 8644 reduced, whereas high doses enhanced, the antinociception induced by $s c$ opioids in rodents $(14,16)$. The dualistic effect of BAY K 8644 may derive from its $\mathrm{Ca}^{2+}$ agonistic property, which is prominent at low concentrations but declines at higher concentrations (15). Intracerebroventricular EGTA, but not EDTA increases morphineand $\kappa$-agonist-induced antinociception in the mouse tail-flick test.

In general, L-type $\mathrm{Ca}^{2+}$-channel antagonists potentiate opioid-induced antinociception in several rodent pain models (for references, see Table 3). However, there are reports showing antagonistic effects of nimodipine against the antinociception evoked by morphine in mice (10) or by the $\kappa$-agonist U69593 in rats (33).

The morphine-induced antinociception was potentiated by $\omega$-CgTX following $i c v$ administration in mice, and icv or ip injection in rats (38). The $i c v$ administration of $\omega$ CgTX to rats potentiates the antinociception produced by the $\mu$-agonist DAMGO, and reduces the antinociception evoked by the $\delta$ agonist DADLE (28). We found that the antinociceptive effect of it gentamicin was only additive to morphine antinociception in rats (3). The $i c v \mathrm{Ca}^{2+}$-induced inhibition of opiate antinociception seems to result from a $\mathrm{Ca}^{2+}$ influx through N-type VOCC since its effect was prevented by icv $\omega$-CgTX but not by icv nimodipine (10).

We have recently shown (34) that it $\omega$ CgTX GVIA, but not nimodipine, increased the latency for the rat tail-flick reflex. Nimodipine reduced the antinociception evoked by it DAMGO but did not change the effects of DADLE or bremazocine, $\delta$ - and $\kappa$-opioid agonists, respectively. In contrast, it $\omega$-CgTX GVIA potentiated the antinociceptive effects of DADLE but did not change the effects of DAMGO or bremazocine, thus indicating that the combination of an $\mathrm{N}$-type $\mathrm{Ca}^{2+}$-channel blocker with a $\delta$-opioid agonist would be 
most effective for the management of pain in that model of phasic pain.

$\mathrm{Ca}^{2+}$ influx is considered to be critical in the transmission of persistent but not brief noxious inputs (for a review, see Ref. 7). Taddese and colleagues (49) have shown that the $\mu$-opioid agonist DAMGO inhibits calcium channels in almost all small nociceptors, which mediate persistent pain, but has minimal effects on large nociceptors known to mediate phasic pain. Somatostatin has the opposite specificity, but the effects of both agonists were eliminated by $\omega$-CgTX GVIA, thus indicating that the differences between DAMGO and somatostatin are not due to different $\mathrm{Ca}^{2+}$-channels. However, the antinociceptive effect of $\mathrm{N}$-type $\mathrm{Ca}^{2+}$ channel antagonists has been shown in both phasic and persistent pain models. Therefore, the interactions between opioid agonists and $\mathrm{Ca}^{2+}$-channel antagonists may in fact differ according to the type of noxious stimuli.

\section{Clinical studies}

The usefulness of $\mathrm{Ca}^{2+}$-channel antagonists in the management of clinical pain has also been somewhat controversial, especially regarding the effects of L-type antagonists. An earlier study on this subject indicated that fentanyl-induced analgesia in patients undergoing thoracic surgery was potentiated by the intraoperatory infusion of nimodipine (50). However, the on-demand $i v$ infusion of fentanyl for the control of pain after elective hysterectomy was not significantly different in groups of patients double-blindly assigned to the administration of an additional infusion of either placebo or nimodipine (51). Oral administration of slow-release tablets of nifedipine given 18,9 and $1 \mathrm{~h}$ before the beginning of surgery significantly potentiated the analgesic effect of morphine slowly infused by the $i v$ route in patients submitted to elective hysterectomy or orthopedic surgery (30). However, slow-release nifedipine given orally 12 and $1 \mathrm{~h}$ before surgery did not change significantly the postoperative pain relief produced by epidural fentanyl (52). In our experience, the postoperative pain relief provided by epidural morphine in patients undergoing elective gynecological surgery was significantly enhanced by the sublingual administration of nifedipine (53). In none of these studies did the $\mathrm{Ca}^{2+}$-channel antagonists have an analgesic effect by themselves.

Few reports are presently available regarding the usefulness of $\mathrm{Ca}^{2+}$-channel antagonists in the control of chronic pain. Oral nifedipine at doses increased weekly from $10 \mathrm{mg}$ twice a day to $30 \mathrm{mg}$ twice a day produced complete ( 7 cases), partial ( 2 cases) or no relief (1 case) of pain symptoms in patients suffering from reflex sympathetic dystrophy (54). Nimodipine given orally at a dose of $30 \mathrm{mg}$ every $8 \mathrm{~h}$ for 3 days did not change the analgesia produced by the concomitant use of morphine in the earlier phase of treatment for cancer pain (55). In contrast, oral slow release nimodipine reduced the daily dose of oral morphine required for pain management in cancer patients. In this case, the dose of nimodipine was $60 \mathrm{mg}$ on the first day, and was then increased up to 120 $\mathrm{mg} /$ day divided into four doses. In addition, the antagonist was introduced only when the patients met the criteria for tolerance to morphine (56). A similar design used oral slowrelease nifedipine (15 $\mathrm{mg}$ twice a day) to show that the antagonist significantly reduced the daily intake of oral morphine for the adequate management of cancer pain (57), but nifedipine was effective only 3 to 5 days after the beginning of treatment. Altogether, these data point to the dependency of the improvement of opioid analgesia on an effective plasma concentration of the $\mathrm{Ca}^{2+}$ channel antagonist. Moreover, the efficacy of L-type $\mathrm{Ca}^{2+}$-channel antagonists in the management of chronic pain indicates that pharmacological interference with $\mathrm{Ca}^{2+}$-related events may modify the chronic effects 
of opioid analgesics (56).

Based on the effectiveness of N-type $\mathrm{Ca}^{2+}$ channel antagonists in animal models of pain, recent clinical trials have confirmed that these drugs can provide relief of chronic pain also in human subjects. A dose-dependent analgesic effect of continuous it infusion of SNX111 was demonstrated in one case of intractable deafferentation and phantom limb pain secondary to brachial plexus avulsion and subsequent amputation (58). Thirty patients undergoing elective abdominal hysterectomy, radical prostatectomy or total hip replacement were treated with an it infusion of SNX-111 (ziconotide, 0.7 to $7.0 \mu \mathrm{g} / \mathrm{h}$ ), which was started before the surgical incision and continued for 48 to $72 \mathrm{~h}$ postoperatively. It was shown that the daily patient-controlled administration of morphine was significantly lower in ziconotide-treated than in placebo-treated patients (59). However, dosedependent adverse effects such as dizziness, blurred vision, nystagmus and sedation were noticed in both studies. Continuous it infusion of ziconotide $(0.4$ to $5.3 \mu \mathrm{g} / \mathrm{h})$ in 3 patients suffering from chronic pain, in addition to the aforementioned side effects, also produced potentially serious outcomes, including bradycardia, orthostatic hypotension, nausea and vomiting, coma, ataxia, dysmetria, agitation, hallucination, rash, hypoglycemia, diarrhea, nasal congestion and urinary retention (60).

\section{Conclusions}

The results reviewed here indicate that $\mathrm{Ca}^{2+}$ plays an important role in regulating endogenous pain systems. In addition, they indicate a close relationship between the analgesic effects of opioids and $\mathrm{Ca}^{2+}$ availability in the CNS. Thus, elevation of extracellular free $\mathrm{Ca}^{2+}$ concentration or facilitation of its transmembrane flux reduces the opioid antinociception. On the other hand, reduction of extracellular free $\mathrm{Ca}^{2+}$ concentration or of its transmembrane flux increases opioid antinociception or promotes antinociception by itself.

The experiments with VOCC antagonists revealed that L-, N-, and P/Q-, but not T-type channels are involved in nociception. Antinociception is more frequently obtained with $\mathrm{N}$ - or P/Q-type antagonists than with L-type antagonists. Potentiation of opioid-induced antinociception was more frequently seen with L-type antagonists, while N-type antagonists were only additive to opioid antinociception. In contrast, L-type antagonists prevented the development of opioid tolerance and were more effective than N-type antagonists in reducing symptoms of opioid withdrawal. The experiments also indicated that the interactions between opioid agonists and $\mathrm{Ca}^{2+}$-channel antagonists differ according to the type of noxious stimuli used in each case.

Few clinical studies on the efficacy of $\mathrm{Ca}^{2+}$-channel antagonists for the management of acute or chronic pain are presently available. However, in agreement with the studies performed on laboratory animal models of pain, they indicate the usefulness of Ntype antagonists as analgesics and of L-type antagonists as an alternative to improve opioid analgesia. The analgesic effect of chronic administration of $\mathrm{N}$-type antagonists lacks tolerance, which is an advantage of opioid analgesia. However, the analgesic effect of N-type antagonists was confirmed in patients only when continuous it drug infusion was provided, a procedure that somewhat restricts its usefulness in clinical practice. In addition, more recent studies have reported various potentially dangerous side effects, which certainly limit the clinical use of these drugs. The use of L-type antagonists combined with opioids seems to be an alternative to reduce the intake of opioids for acute and mainly chronic pain management. At present there is no explanation for the mechanism of such a combination but the possibility remains that the use of selective L-type antagonists reduces or prevents the 
development of tolerance to opioid analgesia. Finally, the observation that $\mathrm{N}$ - and $\mathrm{P} / \mathrm{Q}-$ type channels can participate in different phases of the response to persistent noxious stimulation points to the possible clinical usefulness of aminoglycoside antibiotics for the management of persistent pain since this drug class is the only one presently known to act as an antagonist of these types of channels.

\section{References}

1. Zamponi GW \& Snutch TP (1998). Modulation of voltage-dependent calcium channels by $\mathrm{G}$ proteins. Current Opinion in Neurobiology, 8: 351-356.

2. Barritt GJ (1999). Receptor-activated $\mathrm{Ca}^{2+}$ inflow in animal cells: a variety of pathways tailored to meet different intracellular $\mathrm{Ca}^{2+}$ signaling requirements. Biochemical J ournal, 337: 153-169.

3. Rego EM, Corrado AP \& Prado WA (1992). Antinociception induced by intracerebroventricular or intrathecal administration of gentamicin in rats. General Pharmacology, 23: 481-485.

4. Pichler M, Wang ZY, Grabner-Weiss C, Reimer D, Hering $S$, Grabner M, Glossmann H \& Striessnig J (1996). Block of P/ Q-type calcium channels by therapeutic concentrations of aminoglycoside antibiotics. Biochemistry, 35: 14659-14664.

5. Venegas H \& Schaible HG (2000). Effects of antagonists to high-threshold calcium channels upon spinal mechanisms of pain, hyperalgesia and allodynia. Pain, 85: 9-18.

6. Smith FL \& Dewey WL (1992). Evidence that endogenous opioids mediate the antinociceptive effects of intrathecally administered calcium in mice. J ournal of Pharmacology and Experimental Therapeutics, 262: 995-1003.

7. Coderre TJ \& Melzack R (1992). The role of NMDA receptor-operated calcium channels in persistent nociception after formalin-induced tissue injury. J ournal of Neuroscience, 12: 3671-3675.

8. Ferreira SH \& Nakamura M (1979). II Prostaglandin hyperalgesia: the peripheral analgesic activity of morphine, enkephalins and opioid antagonists. Prostaglandins, 18: 191-200.

9. Ben Sreti M M , Gonzalez J P \& Sewell RDE (1983). Effects of elevated calcium and calcium antagonists on 6,7-benzomorphan-induced analgesia. European J ournal of Pharmacology, 90: 385-391.

10. Smith FL \& Stevens DL (1995). Calcium modulation of morphine analgesia: role of calcium channels and intracellular pool calcium. J ournal of Pharmacology and Experimental Therapeutics, 272: 290-299.

11. Harris RA, Loh HH \& Way EL (1975). Effects of divalent cations, cation chelators and an ionophore on morphine analgesia and tolerance. J ournal of Pharmacology and Experimental Therapeutics, 195: 488498.

12. Dogrul A \& Yesilyurt O (1998). Effects of intrathecally administered aminoglycoside antibiotics, calcium-channel blockers, nickel and calcium on acetic acid-induced writhing test in mice. General Pharmacology, 30: 613-616.

13. Quijada L, Germany A, Hemández A \& Contreras E (1992). Effects of calcium channel antagonists and BAY K 8644 on the analgesic response to pentazocine and U 50488H. General Pharmacology, 23: 837-842.

14. Kuzmin AV, Patkina NA \& Zvartau EE (1994). Analgesic and reinforcing effects of morphine in mice. Influence of Bay K8644 and nimodipine. Brain Research, 652: 1-8.

15. Hoffmeister F \& Tettenborn D (1986). Calcium agonists and antagonists of the dihydropyridine type: antinociceptive effects, interference with opiate- $\mu$-receptor agonists and neuropharmacological actions in rodents. Psychopharmacology, 90: 299-307.

16. Dierssen M, Flórez J \& Hurlé MA (1990). Calcium channel modulation by dihydropyridines modifies sufentanil-induced antinociception in acute and tolerant conditions. Naunyn-Schmiedeberg's Archives of Pharmacology, 342: 559-565.

17. Schmidt WK \& Way EL (1980). Hyperalgesic effects of divalent cations and antinociceptive effects of a calcium chelator in naive and morphine-dependent mice. J ournal of Pharmacology and Experimental Therapeutics, 212: 22-27.

18. Malmberg AB \& Yaksh TL (1994). Voltage-sensitive calcium channels in spinal nociceptive processing: blockade of $\mathrm{N}$ and P-type channels inhibits formalin- induced nociception. J ournal of Neuroscience, 14: 4882-4890.

19. Weissman R, Gestslev V, Pankova IA, Schrieber S \& Pick CG (1999). Pharmacological interaction of the calcium channel blockers verapamil and flunarizine with the opioid system. Brain Research, 818: 187-195.

20. Miranda HF, Pelissier $T \& \&$ Sierralta $F$ (1993). Analgesic effects of intracerebroventricular administration of calcium channel blockers in mice. General Pharmacology, 24: 201-204.

21. Del Pozo E, Ruiz-Garcia C \& Baeyens J M (1990). Analgesic effects of diltiazem and verapamil after central and peripheral administration in the hot-plate test. General Pharmacology, 21: 681-685.

22. Contreras E, Tamayo L \& Amigo M (1988) Calcium channel antagonists increase morphine-induced analgesia and antagonize morphine tolerance. European J ournal of Pharmacology, 148: 463-466.

23. Al-Humayyd MS (1991). Effect of diltiazem, nifedipine and verapamil on the antinociceptive action of acetylsalicylic acid in mice. General Pharmacology, 22: 121125.

24. Miranda HF, Bustamante D, Kramer V, Pelissier T, Saavedra H, Paeile C, Fernandez E \& Pinardi G (1992). Antinociceptive effects of $\mathrm{Ca}^{2+}$ channel blockers. European J ournal of Pharmacology, 217: 137-141.

25. Benedek G \& Sziksay M (1984). Potentiation of thermoregulatory and analgesic effects of morphine by calcium antagonists. Pharmacological Research Communications, 16: 1009-1018.

26. Chaplan SR, Pogrel J W \& Yaksh TL (1994) Role of voltage-dependent calcium channel subtypes in experimental tactile allodynia. J ournal of Pharmacology and Experimental Therapeutics, 269: 1117-1123.

27. Omote K, Sonoda H, Kawamata M, Iwasaki H \& Namiki A (1993). Potentiation of antinociceptive effects of morphine by calcium-channel blockers at the level of 
the spinal cord. Anesthesiology, 79: 746752.

28. Spampinato $S$, Speroni $E$, Govoni $P$, Pistacchio E, Romagnoli C, Murari G \& Ferri S (1994). Effect of $\omega$-conotoxin and verapamil on antinociceptive, behavioural and thermoregulatory responses to opioids in the rat. European J ournal of Pharmacology, 254: 229-238.

29. Diaz A \& Dickenson AH (1997). Blockade of spinal N- and P-type, but not L-type, calcium channels inhibits the excitability of rat dorsal horn neurones produced by subcutaneous formalin inflammation. Pain, 69: 93-100.

30. Carta F, Bianchi M, Argenton S, Cervi D, Marolla G, Tamburini M, Breda M, Fantoni A \& Penerai AE (1990). Effect of nifedipine on morphine-induced analgesia. Anesthesia and Analgesia, 70: 493-498.

31. Wong CH, Dey P, Yarmush J, Wu WH \& Zbuzek VK (1994). Nifedipine-induced analgesia after epidural injection in rats. Anesthesia and Analgesia, 79: 303-306.

32. Rego EM, Corrado AP \& Prado WA (1990). Antinociceptive effects of calcium channel blockers in the rat. Brazilian J ournal of Medical and Biological Research, 23: 297305.

33. Barro $M$, Ruiz F \& Hurlé MA (1995). אOpioid receptor mediated antinociception in rats is dependent on the functional state of dihydropyridine-sensitive calcium channels. Brain Research, 672: 148-152.

34. Lia EM \& Prado WA (1999). Effects of intrathecal L- and N-type calcium channel blockers on the antinociception evoked by opioid agonists in the rat tail flick test. Acta Physiologica, Pharmacologica et Therapeutica Latinoamericana, 49: 195203.

35. Malmberg AB \& Yaksh TL (1995). Effect of continuous intrathecal infusion of $\omega$ conopeptides, N-type calcium-channel blockers, on behavior and antinociception in the formalin and hot-plate tests in rats. Pain, 60: 83-90.

36. Corrado AP, Pimenta de Morais I \& Prado WA (1989). Aminoglycoside antibiotics as a tool for the study of the biological role of calcium ions. Acta Physiologica et Pharmacologica Latinoamericana, 39: 419-430.

37. Prado WA, Tonussi CR, Rego EM \& Corrado AP (1990). Antinociception induced by intraperitoneal injection of gentamicin in rats and mice. Pain, 41: 365371.

38. Basilico L, Parolaro D, Rubino T, Gori E \& Giagnoni $G$ (1992). Influence of $\omega$-conotoxin on morphine analgesia and withdrawal syndrome in rats. European J our- nal of Pharmacology, 218: 75-81.

39. Wang $Y X$, Pettus $M$, Gao D, Phillips $C \&$ Bowersox SS (2000). Effects of intrathecal administration of ziconotide, a selective neuronal $\mathrm{N}$-type calcium channel blocker, on mechanical allodynia and heat hyperalgesia in a rat model of postoperative pain. Pain, 84: 151-158.

40. Bowersox SS, Gadbois T, Singh T, Pettus M, Wang YX \& Luther RR (1996). Selective N-type neuronal voltage-sensitive calcium channel blocker, SNX-111, produces spinal antinociception in rat models of acute, persistent and neuropathic pain. J ournal of Pharmacology and Experimental Therapeutics, 279: 1243-1249.

41. Wang $Y X$, Gao D, Pettus M, Phillips $C \&$ Bowersox SS (2000). Interactions of intrathecally administered ziconotide, a selective blocker of neuronal N-type voltagesensitive calcium channels, with morphine on nociception in rats. Pain, 84: $271-$ 281.

42. Ocaña M \& Baeyens J M (1991). Analgesic effects of centrally administered aminoglycoside antibiotics in mice. Neuroscience Letters, 126: 67-70.

43. Atamer-Simsek $\mathrm{S}$, Ölmez-Salvarli $\mathrm{H}$, Güç $O \&$ Eroglu L (2000). Antinociceptive effect of amikacin and its interaction with morphine and naloxone. Pharmacological Research, 41: 355-360.

44. Law PY \& Loh HH (1999). Regulation of opioid receptor activities. J ournal of Pharmacology and Experimental Therapeutics, 289: 607-624.

45. Besson J M \& Chaouch A (1987). Peripheral and spinal mechanisms of nociception. Pharmacological Reviews, 67: 67185.

46. Guerrero-M uñoz F \& Fearon Z (1982). Opioids/opiates analgesic response modified by calcium. Life Sciences, 31: 1237-1240.

47. Díaz A, Flórez J, Pazos A \& Hurlé MA (2000). Opioid tolerance and supersensitivity induce regional changes in the autoradiographic density of dihydropyridinesensitive calcium channels in the rat central nervous system. Pain, 86: 227-235.

48. Michaluk J, Karolewicz B, AntkiewiczMichaluk L \& Vetulani J (1998). Effects of various $\mathrm{Ca}^{2+}$ channel antagonists on morphine analgesia, tolerance and dependence, and on blood pressure in the rat. European J ournal of Pharmacology, 352: 189-197.

49. Taddese A, Nah SY \& McCleskey EW (1995). Selective opioid inhibition of small nociceptive neurons. Science, 270: 13661369.

50. Bormann BV, Boldt J, Sturm G, Kling D,
Weidler B, Lohmann E \& Hempelmann G (1985). Calciumantagonisten in der Anästhesie. Additive Analgesie durch Nimodipin während cardiochirurgischer Eingriffe. Anaesthesist, 34: 429-434.

51. Lehman KA, Kriegel R \& Ueki M (1989). Zur klinischen Bedeutung von Arzneimittelinteraktionen zwischen Opiaten und Kalziumantagonisten. Eine randomisierte Doppeblindstudie mit Fentanyl und Nimodipin im Rahmen der postoperativen intravenösen On-Demand Analgesie. Anaesthesist, 38: 110-115.

52. Garcia LV (1995). Efeito da nifedipina na analgesia induzida pelo fentanil. Doctoral thesis, Faculdade de Medicina de Ribeirão Preto, USP, Ribeirão Preto, SP, Brazil.

53. Pereira IT, Prado WA \& Dos Reis MP (1993). Enhancement of the epidural morphine-induced analgesia by systemic nifedipine. Pain, 53: 341-355.

54. Prough DS, McLeskey CH, Poehling GG, Koman LA, Weeks DB, Whitworth T\& Semble EL (1985). Efficacy of oral nifedipine in the treatment of reflex sympathetic dystrophy. Anesthesiology, 62: 796799.

55. Roca G, Aguilar J L, Gomar C, Mazo V, Costa J \& Vidal F (1996). Nimodipine fails to enhance the analgesic effect of slow release morphine in the early phases of cancer pain treatment. Pain, 68: 239-243.

56. Santillán R, Maestre J M, Hurlé MA \& Flórez J (1994). Enhancement of opiate analgesia by nimodipine in cancer patients chronically treated with morphine: a preliminary report. Pain, 58: 129-132.

57. Lima ICPR (1996). Efeito da nifedipina na analgesia de pacientes com dor crônica neoplásica em uso de morfina. Master's thesis, Faculdade de Medicina de Ribeirão Preto, USP, Ribeirão Preto, SP, Brazil.

58. Brose WG, Gutlove DP, Luther RR, Bowersox SS \& McGuire D (1997). Use of intrathecal ziconotide, a novel, N-type, voltage-sensitive, calcium channel blocker, in the management of intractable brachial plexus avulsion pain. Clinical J oumal of Pain, 13: 256-257.

59. Atanassoff PG, Hartmannsgruber MWB, Thrasher J, Wermeling $D$, Longton $W$, Gaeta R, Singh T, Mayo M, McGuire D \& Luther RR (2000). Ziconotide, a new Ntype calcium channel blocker, administered intrathecally for postoperative pain. Regional Anesthesia and Pain Medicine, 23: 274-278.

60. Penn RD \& Paice J A (2000). Adverse effects associated with the intrathecal administration of ziconotide. Pain, 85: 291296. 